\title{
Peertechz
}

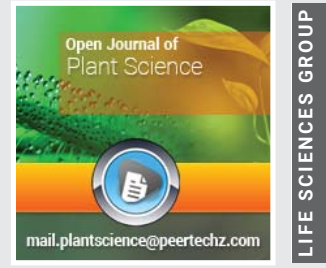

\section{Effects of crop evolution under domestication and narrowing genetic bases of crop species}

\author{
Temesgen Begna* \\ Ethiopian Institute of Agricultural Research, Chiro National Sorghum Research and Training Center P. \\ O. Box 190, Chiro, Ethiopia
}

Received: 14 April, 2021

Accepted: 28 April, 2021

Published: 29 April, 2021

*Corresponding author: Temesgen Begna, Ethiopian Institute of Agricultural Research, Chiro National Sorghum Research and Training Center P. O. Box 190, Chiro, Ethiopia, E-mail: tembegna@gmail.com

Keywords: Domestication; Evolution; Genetic base; Genetic erosion

https://www.peertechzpublications.com

\section{Check for updates}

\begin{abstract}
Crop improvement is very crucial to satisfy the world demand in the presence of different challenges like climate change, reducing arable land and increasing population growth. Crop improvement program is continuously striving to increase crop yield, enhance crop quality and improve crop tolerance to biotic and abiotic stresses. Domestication has a great role in increasing agricultural productivity through selecting suitable crop plants to human beings like high yielding varieties with resistance to biotic and abiotic stresses, improved nutritional quality, big seed and fruit size, non-shattering, reduction of seed dispersal mechanisms, a more compact growth habit, early matured crop plants. Domesticated food crops are derived from a phylogenetically diverse assemblage of wild ancestors through artificial selection for different traits. Plant breeding and domestication of crop plants have a profound impact on the genetic diversity through selecting the desirable crops by neglecting other crop plants with undesirable traits. Domestication of crop plants shifted from hunter-gatherer to agricultural societies which leaded the rise of modern civilization. The amount or quantum of genetic diversity available in a breeding population is referred to as genetic base of that population. In other words, genetic base represents spectrum of genetic variability in a plant breeding population. Depending upon the amount of genetic diversity present in a plant breeding population, genetic base is of two types, viz. broad genetic base and narrow genetic base. Plant populations that are composed of several pure lines, inbred lines or heterozygotes and homozygotes are said to have broad genetic base. Examples of such populations are mass selected varieties, multiline varieties, synthetics, composites and land races. Such genotypes have wider adaptation to environmental changes. Those plant populations that have been developed from single homozygote or heterozygote are-said to have narrow genetic base. Examples of such populations are pure line variety, varieties developed by backcross, pedigree method bulk method, and single seed decent method, clonal variety and hybrids between two inbred lines or pure lines. Genetic loss is directly connected with the reduction of genetic diversity including the loss of individual genes and as well as the loss of particular combinations of genes such as those manifested in locally adapted landraces. Eventually, genetic erosion is the depletion in population variation because of inbreeding and genetic drift which is largely causes the endangerment of small isolated populations. Narrowing of genetic diversity might result the complete loss of crop plants.
\end{abstract}

\section{Introduction}

Agriculture was started before 10,000 years ago during the first crops were domesticated in the Fertile Crescent [1]. Plant breeding is relying on the genetic variation and selection of desirable crop plant through identifying phenotypes. Some of the first domesticated plants are thought to be the cereals wheat, barley, millet and emmer [2]. During domestication, phenotypers were selected crop plant with big grain size and non-shattering seeds. Agriculture was launched with domestication of wild plants through selecting plants with the desirable characters that preferred by societies to be brought under human management. Domestication of plant species led shift hunter-gatherers to sedentary agriculturalists that ultimately resulted in the development of complex societies.
There is genetic alteration in the domestication process that led to striking morphological and behavioral changes in domesticated organisms compared with wild progenitors. The difference between domesticated plants and their wild progenitors in morphology, physiology and anatomy is known as domestication syndrome. The domestication syndrome is group traits that arise from human preferences for the betterment of domestication practices. Domestication syndrome has reduced genetic diversity associated with the fact that the man used a limited number of wild progenitors to select the desired traits [3]. The problem of bottlenecks in the domestication due to selection of only few individuals and reproductive isolation among domesticated and wild relatives' impedes in further improvements of genetic diversity of crop plants. 
The basic requirements and steps of domestication is the presence of natural population with sufficient genetic variation to allow phenotypic variation for traits desirable to humans. Genetic resources are very critical in the development of agriculture. Genetic resources are continuously providing inputs for yield stability and growth. The transformation of wild species into elite cultivars through domestication entails evolutionary responses in which plant populations adapt to selection. Domestication is the evolutionary process in which wild plants genetically, morphologically and physiologically changed by imposing selection for different desires [4]. The transformation of wild ancestors into modern elite cultivars trough domestication and evolution contributes very important role in producing global food and crop plant improvement. Domestication is the transition of the living standard of human being from hunting, gathering to modern agriculture [5]. Domestication is a routine activity beginning with the wild species, then formation of the cultivated species, then selection of improved genotypes of the species by growers (called landraces), then to modern cultivars from scientific breeding.

Biodiversity is broad tem that is defined as the quantity of species and the variety of environments in which species or genes are present [6]. Plant genetic diversity is playing a key role in the continuation of agricultural development with significant improvement in different morphological and agronomical characteristics [7]. Crop species with narrow genetic diversity are susceptible to emerging pathogens or other constraints leading to loss of productivity and this may lead to a serious decline in the areas of adaptation [8]. Crop plant genetic improvement is the changing of plants to satisfy human needs. The process of domestication involved in the continues identification of certain desirable wild species combined with a process of selection of high yielding varieties with resistance to biotic and abiotic stresses, improved nutritional quality, big seed and fruit size, non-shattering, reduction of seed dispersal mechanisms, a more compact growth habit, early matured crop plants.

Conventional plant breeding refers to the selection of superior genotypes from genetically diverse populations derived from sexual recombination. Plant breeding is primarily depends on presence of substantial genetic variation to address the maximum genetic yield potential of the crops and exploitation of this variation through effective selection for improvement [9]. There is substantial genetic improvement progress of crop plants through conventional breeding procedures. Conventional breeding is mainly focused on the improvement of the observable traits like productivity, quality and resistance to biotic and abiotic stresses. However, there are limitations to the progress of conventional breeding. These limitations are due to sexual barrier, impossible to incorporate genes from nonrelated species or to incorporate small changes without disturbing the particular combination of genes that make a particular type unique. Landraces are locally adapted or traditional plant varieties that evolved and improved by farmers over many generations without the help of modern breeding schemes. Today, the landraces are displaced from marketdriven production because of their lower yields, susceptible to biotic and abiotic stresses and poorer postharvest shelf life in comparison with modern varieties. In the progress of evolution and domestication, landraces are neglected to develop modern varieties with specific desirable traits. This might lead to genetic erosion if the land races are not conserved at national and international germplasm conservation.

Alandracerepresents theequilibriumbetweenheterogeneous and heterozygous genotypes within a population of a crop that is maintained by continuous multiplication under a given set of climatic, soil and husbandry conditions. Landraces have substantial contribution for crop improvement in providing genetic materials. Despite its economic importance, land races were replaced by single dominant modern variety that promotes genetic erosion [10]. To meet the challenges in crop improvement, efforts were made to widen the genetic base by collecting and conserving germplasm across the world before it is lost forever, which led to the assembly of large collections at the national and international gene banks [11].

Agriculture is faced for many challenges such as human population growth, climate change, malnutrition, poverty, hunger and other stressors. Overcoming these difficult challenges will be harder in the absence plant genetic improvement to increase agricultural productivity through addressing the problem of yield reduction and its links with pest management and climate change [12]. However, agriculture must change to meet the rising demand of global population by the transition of agricultural growth to effective modern agricultural development. In this regard, domestication of crop plants was contributing the crucial role through changing the genetic potential of crop plant to the advanced level to reach the molecular marker stages. The objective/s of the paper was to understand how crop evolution under domestication has led to increase productivity of crop species and know how crop evolution under domestication has narrowed genetic bases of crop species.

\section{Crop evolution under domestication and narrowed ge- netic bases}

Genetic diversity: Genetic diversity ha paramount role in the perpetuation of a species through offering adaptation mechanisms to biotic and abiotic environmental stresses and enables change in the genetic composition to cope with changes in the environment [13]. Plant genetic diversity is playing a key role in the continuation of agricultural development with significant improvement in different morphological and agronomical characteristics. Plant breeding is primarily relied on the variation exist in the genetic diversity of cultivated and their wild relatives together for further improvements. Plant phenotyping is defined as the investigation of plant characters by researchers for yield, quality and resistance to biotic and abiotic stresses. Genetic variation and selection are the two basic principles of plant breeding. Additive (heritable) and non-additive variance (dominance and epitasis) are the important components of genetic variance of any quantitative traits [14]. Genetic diversity is the extent of genetic variation available among crop species to use in improvement program The presence of sufficient genetic variation is a key for the 
success of breeding program. Genetic diversity determines the efficiency and effectiveness of improvement which may result in enhanced food production. From plant breeding aspects, classification of genetic variability to respective heterotic group is critical for the development of vigorous and outstanding hybrids in terms of economically important traits. Genetic diversity is providing vital protection to other nature against climate change, pests and diseases stresses.

Domestication is the transformation of wild progenitors to the cultivated species through continues selection for desirable traits of crop plants in order to satisfy the human demand [15]. Plants domesticated in different agro-ecological environments of the world for the different desirable traits that demanded by the cultivators. Domestication is about artificial selection of crop plants with the desired traits in order to ensure food and nutritional security [3]. There is genetic alteration of morphological and agronomical characters in domestication processes for adaptation of crop plants [16]. McCouch [17] indicated domestication is about adapting the high yielding varieties with resistance to biotic and abiotic stresses, improved nutritional quality, big seed and fruit size, non-shattering, reduction of seed dispersal mechanisms, a more compact growth habit, early matured crop plants. In the domestication process wild plants have been evolved into crop pants through artificial selection in order to satisfy the specific human demand. Artificial selection of crop plants causes alteration for the transformation of wild species to domesticate [18]

Genetic erosion is the depletion of genetic variability due to several factors over a particular period of time in a particular location. The loss can be include individual genes or combination of genes. Genetic loss is the reduction of genetic diversity over time [13]. The frequent development and adoption of genetically uniform crop varieties makes the crop population more susceptible to a widespread disease and pest infestation [19]. Genetic loss can be occurred since diseases and pests evolved and attacked the host plant resistance due to genetic uniformity increases. Genetic diversity is affected by several different factors. There is evolutionary forces continuously changing genetic frequencies of crop species which affects the genetic diversity of a population. Selection, mutation, gene flow and genetic drift are the evolutionary forces which affects gene pool of a given population. Genetic uniformity causes genetic susceptibility to different biotic and abiotic stresses and is resulted genetic loss of crop plants [20] Figure 1.

\section{The role of landraces and modern varieties in narrowing genetic bases of crops}

Narrowing in genetic base is a serious problem in the modern agriculture that caused due to selection of best performed cultivars with the preferred traits. The loss of genetic variation in crop plants due to agricultural modernization is called genetic erosion. The main cause of genetic erosion is the replacement of diversity of land races with few modern varieties. Genetic erosion has negative developmental effect when loss of genetic diversity has profoundly narrowed the genetic base of modern crop varieties [21]. Genetic erosion is defined as the loss of genetic diversity and commonly refers to the reduction in the
Genetic diversity index

$\begin{array}{lllll}0 & 0.05 & 0.1 & 0.15 & 0.2\end{array}$

0.25

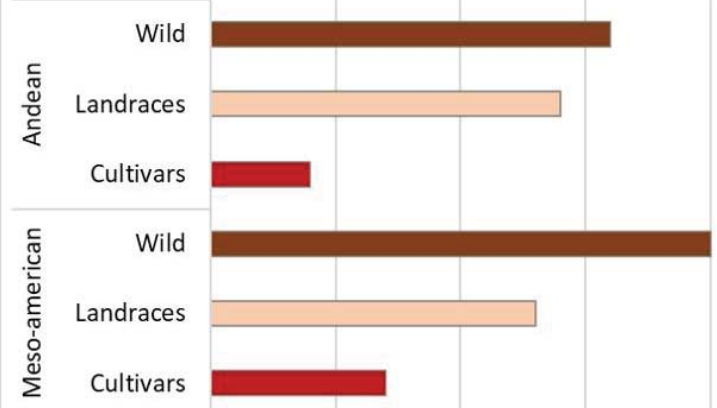

Figure 1: Reduction of genetic diversity during evolution of common bean (Phaseolus vulgaris) in the Andean and Meso-American centers of origin Source: Redrawn from Gepts (2018).

quantities of specimens of a species [22]. Green revolution was the transition of cultivation of landraces to modern varieties to increase the agricultural productivity using improved varieties, excessive agricultural inputs and mechanized agriculture. The term Green Revolution refers to the renovation of agricultural practices beginning in Mexico in the 1940s. Because of its success in producing more agricultural products there, green revolution technologies spread worldwide in the 1950 s and 1960s, significantly increasing the number of calories produced per acre of agriculture.

The varieties developed during green revolution were high yielder varieties meaning they were domesticated plants bred specifically to respond to fertilizers and produce an increased amount of grain per acre planted. Genetic alteration and narrowing genetic base started with the first domestication of wild plants. Green revolution has great impact on the ecological and societal of relations of the world that can be summarized as follows: (1) loss of landraces that indigenous to the country, (2) the loss of soil nutrients making it unproductive, (3) excessive use of pesticides increases the presence of its residues in foods and environment [23], (4) the farmers shift to unsustainable practices to obtain more yield, (5) increased rates of suicide among farmers, (6) unable to withstand the increasing expenses for farming and debts small farmers sold their lands to large commercial farmers, and (7) unable to withstand the food inflation and economic crisis the farmers left farming resorting to other occupation. The dramatic increase of food grain production since after green revolution in the subsequent decades is directly traceable to these crop improvement programs. This green revolution is also the beginning of genetic erosion in the world. The other causes of genetic erosion are population pressure, environmental degradation, legislation or policy, pests/weeds/diseases, changing agricultural systems and overexploitation of species Figure 2.

Genetic diversity is the backbone of a nation's food security and the basis of economic development as a whole. The term genetic erosion refers to both the loss of species and the reduction of variety. Replacement of landraces that evolved with and has been genetically improved by traditional agriculturists, 
but has not been influenced by modern breeding practices or traditional varieties by modern varieties or High Yielding Varieties is one of the most important reasons. The landraces of a primary centre of origin are assumed to contain many valuable genes particularly for resistance or tolerance to various biotic and abiotic stresses and hence hold promise for their utilization in future plant-breeding programs. Genetic erosion is the loss of genetic diversity, including the loss of individual genes and the loss of particular combinations of genes (i.e. of gene-complexes) such as those manifested in locally adapted landraces. The term genetic erosion is sometimes used in a narrow sense, i.e. the loss of genes or alleles, as well as more broadly, referring to the loss of varieties. There are a number of different ways to represent the problems of genetic erosion. One of the most useful indicators is the narrowness of the food base. At another level, evidence regarding genetic erosion can be presented in terms of the replacement of landraces and traditional varieties Figure 3.

\section{Dangers of genetic uniformity}

The loss of genetic diversity of species of the given population promotes genetic uniformity that leads to genetic erosion of the crop plants. There are multitude reasons for the loss of genetic variation of crop plants. Some of them are: Adoption of genetically uniform crop varieties that makes the crop varieties more vulnerable to biotic and abiotic stresses, replacement of landraces and wild relatives by commercially developed modern varieties, failurities in resistance to different diseases either host specific or non-host specific diseases [20]. Genetic uniformity invites disaster because it

\section{Technologies introduced through the Green} Revolution have helped farmers increase yields.

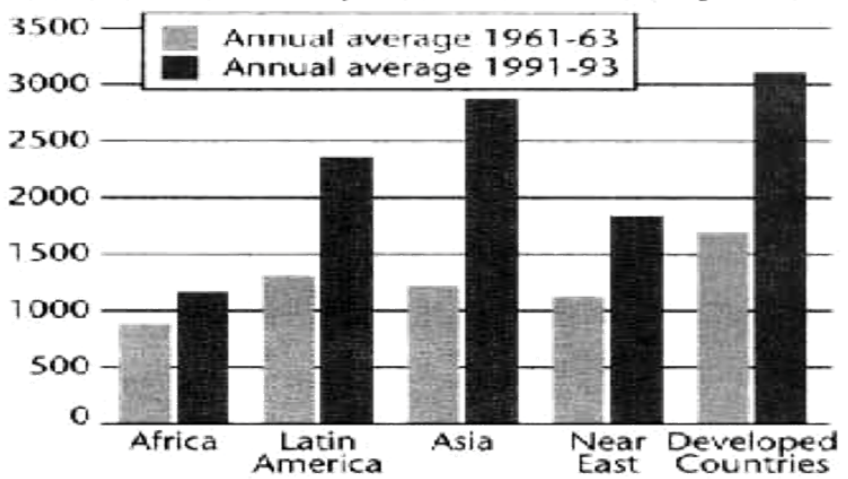

Figure 2: Cereal yield in kilograms per hectare.

Source: Food and Agriculture Organization of the United Nations.

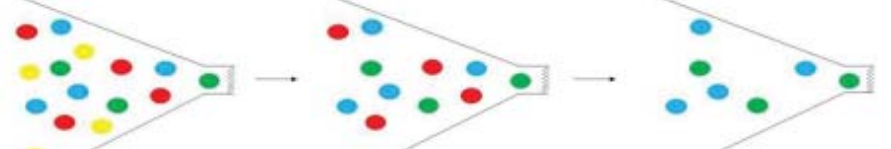

gure 3: Conceptual representation of a reduction in genetic diversity during domestication and development of modern cultivars. Colors represent the diversity of alleles within a population.

Source: Redrawn from Gepts (2018). makes a crop vulnerable to attack a pest or disease that strikes one plant quickly spreads throughout the crop. The wise use of crop genetic diversity in developing improved crops can contribute significantly to protecting the environment. Crop varieties that are resistant to pests and diseases can reduce the need to apply harmful pesticides.

The some important factors interact to increase the potential for crop failure: The degree of uniformity for the trait controlling susceptibility to the hazardous agent or environmental stress and the extent of monoculture of the susceptible variety. The greater the uniformity for a susceptible trait and the more extensive the area of cultivation, the greater the risk of disaster. In the case of pest or pathogen attack, two additional factors enhance the risks: (1) a highly dispersible disease or insect agent, and (2) favorable environmental conditions for the multiplication of the agent. The continuous and intensive cultivation of varieties of narrow genetic base results in genetic vulnerability and genetic erosion. Genetic vulnerability is the susceptibility of most of the cultivated varieties of a crop species to biotic and abiotic stresses due to similarities in their genotypes. The main causes of genetic vulnerability are narrow genetic base, widespread of dominant Varieties (problem aggravated by the widespread use of one or a few genetically uniform varieties over a large hectare (spatial dominance), failure of vertical resistance (effected by a single or a few genes (monogenic or oligogenic) and highly specific and liable to changes in races of pathogens [24] Table 1.

\section{Effect of genetic erosion in crop plants}

Genetic erosion is the depletion of genetic variability due to several factors over a particular period of time in a particular location. The loss can be include individual genes or combination of genes. Genetic loss is the reduction of genetic diversity over time [13]. Genetic loss primarily caused due to the modernization of agriculture which embraces the replacement of landraces with the new improved varieties. The loss of genetic variation is becoming a bottleneck in plant breeding activities. Genetic loss can be occurred at three different levels: crop, variety and allele. Climate changes, deforestation, environmental degradation, urbanization, replacement of local land races are major cause of genetic loss. There are three different methods to quantify genetic loss: (1) Genetic erosion as a complete loss of a crop, variety or allele [25]. (2) Genetic erosion as an alleviation in richness [26]. (3) Genetic erosion as an alleviation in evenness [27]. Genetic loss as depletion in evenness originates from the variability indicators used in population genetics, such as Shannon's index [28] and Nei's gene diversity index [29]. Genetic diversity is measured using frequencies of genes within a group of genotypes in a specified region. Diversity level is reduced because of dominant single genotypes or alleles. Genetic loss at ex situ conservation can be occurred because of depletion of genes as a result of regeneration and storage practices [30].

\section{Conclusion}

Narrowing the genetic bases of crop plats are becoming a serious problems in the development new and superior varieties 
Table 1: History and Consequences cof Genetic Vulnerability of Crop Plants.

\begin{tabular}{|c|c|c|c|c|}
\hline Country & Crop & Year & Cause & Consequence \\
\hline Ireland & Potato & 1840 & $\begin{array}{c}\text { Phytophthora infestans } \\
\text { devastated a new variety, } \\
\text { Lumpers }\end{array}$ & $\begin{array}{l}\text { The Irish Potato Famine, } \\
\text { millions of Irish people died } \\
\text { and two million emigrated }\end{array}$ \\
\hline India & Rice & 1943 & Cochliobolus miyabeanus & The great Bengal Famine \\
\hline USA & Maize & 1972 & $\begin{array}{l}\text { Helminthosporium maydis } \\
\text { devastated new hybrids } \\
\text { (Texas Male Sterile, TMS) }\end{array}$ & $\begin{array}{l}\text { Wiped out } 1 / 4 \text { of the US corn or } \\
\text { a loss of one billion USD }\end{array}$ \\
\hline France & $\begin{array}{l}\text { Grape } \\
\text { Vine }\end{array}$ & - & Phylloxera vertifoliae & Grapevine totally wiped out \\
\hline
\end{tabular}

Source: Food and Agriculture Organization of the United Nations

with useful characteristics. Depletion of genetic variation is not only about the replacement of a diversity of land races with one or a few modern varieties, but involves the loss of farmers' indigenous knowledge of and ability to manage their own plant genetic resources. Creating sufficient genetic variation for golden crop improvement is becoming challenges to keep improving genetic yield potential. Nowadays, plant breeders are utilizing genetic materials without knowing its genetic background such as exotic non-adapted, exotic adapted and existing genetic material as a source of new alleles that protect and improve genetic gain through selection. In ensuring food and nutritional security, genetic diversity is contributing very amble quantity. Knowledge of genetic diversity of the genetic material is very critical in crop improvement. Effective selection is highly important in any crop improvement where the sufficient genetic variation is available for different characters. The genetic variability analysis of crop cultivars for different agronomical and morphological characters are very critical in providing opportunity to select a number of promising cultivars.

Genetic variation is the basic foundation for the continuous development of new superior varieties. Hence characterization of genetic materials using different statistical tools is critical in the crop improvement program. Improvement for both qualitative and quantitative traits are primarily relying on the genetic diversity. Genetic diversity is the extent of genetic variation available among crop species to use in improvement program. The presence of sufficient genetic variation is a key for the success of breeding program. Genetic diversity has paramount importance for the development of superior varieties in terms of yield and other desirable traits. It is also very crucial in the production of superior hybrids and desirable recombinants. Genetic diversity determines the efficiency and effectiveness of improvement which may result in enhanced food production. From plant breeding aspects, classification of genetic variability to respective heterotic group is critical for the development of vigorous and outstanding hybrids in terms of economically important traits. Genetic diversity is providing vital protection to other nature against climate change, pests and diseases stresses.

Domestication plays a key role in crop plant improvements starting from the very beginning of evolutionary process and primitive life of human being. Domestication is a continuous process and bringing wild species of plants by considering the agro-ecological environment plays a significant role for the ease of adaptation. Before domesticating plants to some new areas, consideration of ecology is very critical to maintain yield potential, stability, resistance, tolerance and other important traits that they have in their original place. Generally domestication of crop plants with their appropriate ecologies is used to maintain sustainable yielding ability without reducing actual potential of crop plants. Domestication is the transformation of wild progenitors to the cultivated species through continues selection for desirable traits of crop plants in order to satisfy the human demand. A success in crop improvement is depending on the quantity of genetic variation exist in the genetic materials and selection for genetically superior genotypes.

\section{References}

1. Brown TA, Jones MK, Powell W, Allaby RG (2009) The complex origins of domesticated crops in the Fertile Crescent. Trends Ecol Evol 24: 103-109. Link: https://bit.ly/3aOkbvY

2. Sang $T$ (2009) Genes and mutations underlying domestication transitions in grasses. Plant Physiol 149: 63-70. Link: https://bit.ly/3vmpkU3

3. Begna T (2020) Importance and Impact of Ecological Approaches to Crop Domestication.

4. Harlan JR, Wet JD, Price EG (1973) Comparative evaluation of cereals Evolution 27: 311-325. Link: https://bit.ly/3gKakLz

5. Smith BD (1995) The emergence of agriculture Scientific American Library series. Scientific American Library, New York Google Scholar.

6. Vandermeer J, van Noordwijk M, Anderson J, Ong C, Perfecto I (1998) Global change and multi-species agroecosystems: concepts and issues. Agriculture, Ecosystems \& Environment 67: 1-22. Link: https://bit.ly/2PtLTqu

7. Glaszmann JC, Kilian B, Upadhyaya HD, Varshney RK (2010) Accessing genetic diversity for crop improvement. Curr Opin Plant Biol 13: 167-173. Link: https://bit.ly/3eBUvE6

8. Dyer GA, López-Feldman A, Yúnez-Naude A, Taylor JE (2014) Genetic erosion in maize's center of origin. Proceedings of the National Academy of Sciences 111: 14094-14099. Link: https://bit.ly/2PuXS7j

9. Ribaut JM, Banziger M, Betran J, Jiang C, Edmeades GO (2002) Breeding: Drought Tolerance Improvement in Tropical Maize. Quantitative genetics, genomics, and plant breeding 85 .

10. Rogers DL (2004) Genetic erosion no longer just an agricultural issue. Native Plants Journal 5: 112-122. Link: https://bit.ly/3xxXENG

11. Duvick DN (1986) Plant breeding: past achievements and expectations for the future. Economic Botany 40: 289-297. Link: https://bit.ly/2QElvdZ

12. Searchinger T, Heimlich R, Houghton RA, Dong F, Elobeid A, et al. (2008) Use of US croplands for biofuels increases greenhouse gases through emissions from land-use change. Science 319: 1238-1240. Link: https://bit.ly/2S654YI

13. FAO (2012) FAO moves to halt plant genetic erosion. FAO Media Centre Food and Agriculture Organization of the United Nations, Rome. Link: https://bit.ly/3aHNy2X

14. Cole CT (2003) Genetic variation in rare and common plants. Annual Review of Ecology, Evolution, and Systematics 34: 213-237. Link: https://bit.ly/3xxYdXO

15. Acquaah G (2009) Principles of plant genetics and breeding. John Wiley \& Sons.

16. Rauf S, da Silva JT, Khan AA, Naveed A (2010) Consequences of plant 
breeding on genetic diversity. International Journal of plant breeding 4: 1-21. Link: https://bit.ly/3gHgYSQ

17. McCouch S (2004) Diversifying selection in plant breeding. PLoS Biol 2: .e347. Link: https://bit.ly/3u4WZBm

18. Pickersgill MARTIN (2005) The taxonomy and ethology of the Afrixalus stuhlmanni complex (Anura: Hyperoliidae). Steenstrupia 29: 1-38. Link: https://bit.ly/3nriLg0

19. Duvick DN (1996) Plant breeding, an evolutionary concept. Crop Science 36 539-548. Link: https://bit.ly/3aNRoYF

20. Rogers $P$ (1996) Disturbance ecology and forest management: a review of the literature. Link: https://bit.ly/3nvbs7m

21. De Oliveira L, Martins ER (2002) A quantitative assessment of genetic erosion in ipecac (Psychotria ipecacuanha). Genetic Resources and Crop Evolution 49 607-617. Link: https://bit.ly/3aK4h63

22. Solbrig OT (2000) The theory and practice of the science of biodiversity: a personal assessment. In The Biology of Biodiversity . Springer, Tokyo 107-117. Link: https://bit.ly/2SehPjT

23. Nelson ARLE, Ravichandran K, Antony U (2019) The impact of the Green Revolution on indigenous crops of India. Journal of Ethnic Foods 6: 1-10. Link: https://bit.ly/3nwD8Zw
24. Olsen KM, Wendel JF (2013) A bountiful harvest: genomic insights into crop domestication phenotypes. Annu Rev Plant Biol 64: 47-70. Link: https://bit.ly/3b3fNJZ

25. Tsegaye B, Berg T (2007) Genetic erosion of Ethiopian tetraploid wheat landraces in Eastern Shewa, Central Ethiopia. Genetic Resources and Crop Evolution 54: 715-726. Link: https://bit.ly/3t1oMBn

26. Nabhan GP (2007) Agrobiodiversity change in a Saharan desert oasis, 19192006: historic shifts in Tasiwit (Berber) and Bedouin crop inventories of Siwa Egypt. Economic Botany 61: 31-43. Link: https://bit.ly/2S1QqBm

27. Ford-Lloyd B, Dias SR, Bettencourt E (2006) Genetic erosion and pollution assessment methodologies. Diversity International. Link: https://bit.ly/3b3g0Nh

28. Maughan PJ, Maroof MS, Buss GR, Huestis GM (1996) Amplified fragment length polymorphism (AFLP) in soybean: species diversity, inheritance, and near-isogenic line analysis. Theor Appl Genet 93: 392-401. Link: https://bit.ly/2SbpZJJ

29. Nei M (1977) F-statistics and analysis of gene diversity in subdivided populations. Ann Hum Genet 41: 225-233. Link: https://bit.ly/2QB70Yo

30. Parzies HK, Spoor W, Ennos RA (2000) Genetic diversity of barley landrace accessions (Hordeum vulgare ssp. vulgare) conserved for different lengths of time in ex situ gene banks. Heredity 84: 476-486. Link: https://go.nature.com/2PvDSS3

\section{Discover a bigger Impact and Visibility of your article publication with}

\section{Peertechz Publications}

\section{Highlights}

* Signatory publisher of ORCID

- Signatory Publisher of DORA (San Francisco Declaration on Research Assessment)

* Articles archived in worlds' renowned service providers such as Portico, CNKI, AGRIS, TDNet, Base (Bielefeld University Library), CrossRef, Scilit, J-Gate etc.

* Journals indexed in ICMJE, SHERPA/ROMEO, Google Scholar etc.

* OAI-PMH (Open Archives Initiative Protocol for Metadata Harvesting)

* Dedicated Editorial Board for every journa

* Accurate and rapid peer-review process

* Increased citations of published articles through promotions

* Reduced timeline for article publication

Submit your articles and experience a new surge in publication services (https://www.peertechz.com/submission).

Peertechz journals wishes everlasting success in your every endeavours.

Copyright: (C) 2021 Begna T. This is an open-access article distributed under the terms of the Creative Commons Attribution License, which permits unrestricted use, distribution, and reproduction in any medium, provided the original author and source are credited. 